Abstracta Iranica Abstracta Iranica

Revue bibliographique pour le domaine irano-aryen

Volume 31 | 2011

Comptes rendus des publications de 2008

\title{
Visions of Mughal India: An Anthology of European Travel Writing. London, I.B. Tauris, 2007, 256 p.
}

\section{Colin P. Mitchell}

\section{OpenEdition}

1 Journals

Édition électronique

URL : http://journals.openedition.org/abstractairanica/39592

DOI : 10.4000/abstractairanica.39592

ISSN : 1961-960X

\section{Éditeur :}

CNRS (UMR 7528 Mondes iraniens et indiens), Éditions de l'IFRI

\section{Édition imprimée}

Date de publication : 15 mai 2011

ISSN : 0240-8910

\section{Référence électronique}

Colin P. Mitchell, « Visions of Mughal India: An Anthology of European Travel Writing. London, I.B. Tauris, 2007, 256 p. », Abstracta Iranica [En ligne], Volume 31 | 2011, document 173, mis en ligne le 11 octobre 2012, consulté le 26 septembre 2020. URL : http://journals.openedition.org/abstractairanica/39592 ; DOI : https://doi.org/10.4000/abstractairanica.39592

Ce document a été généré automatiquement le 26 septembre 2020.

Tous droits réservés 


\title{
Visions of Mughal India: An Anthology of European Travel Writing. London, I.B. Tauris, 2007, 256 p.
}

\author{
Colin P. Mitchell
}

ed.

Our understanding of Mughal India is to no small degree bolstered by a significant number of European travel accounts produced in the 16th-18th centuries. While we depend on court chronicles and religio-philosophical treatises to better understand the 'elite' narrative of Mughal India, the day-to-day, quotidian details of life in early modern South Asia are largely absent in such 'indigenous' documents. For this reason, historians of social, gender, urban and economic history are often drawn to the corpus of travel writings of various Europeans. To some degree, this has motivated Michael Fischer to compile a number of such accounts in Visions of Mughal India, although it is also clear that this is a text that would be best used in an undergraduate seminar to provide students access to key primary sources. After a lively preface by William Dalrymple (author of White Mughals and The Last Mughal), Fisher provides a fairly detailed introduction wherein he provides context not only to the Mughals, but also to the genre of travel writing in early modern European society. These accounts are diverse and varied, and they all fall within the period of the 16th and 17th centuries; Fisher wisely avoids the 18th and 19th centuries as the colonial enterprises in India produced a staggering amount of European literature on South Asia. Ten authors are profiled, and the editor has chosen selections from their respective travel accounts; most are taken from published (and translated) texts, although one or two are based on manuscript sources. The first is the Russian horse dealer, Afanasy Nikity, who traveled to India on the eve of Babur's 1526 invasion of the Indo-Gangetic Plain; his account presents an undeniably unique, Russian perspective. Venetians were no doubt well known for their wanderlust, and Fisher provides selections from both Cesare Federici and the famous Niccalao Manucci (author of the multilingual Storia do Mogor). Catholic missionary institutions were also important cultural intermediaries, and here we look to the writings of Antonio Monserrate (Portuguese Jesuit), Sebastian Manrique 
(Portuguese Augustinian), and Domongo Fernandez de Navarrete (Spanish Dominican). Given their religious and cultural mandates, these ecclesiasts and their accounts are particularly valuable for their presentation of specific social customs among the Gentiles (Hindus) and Musulmans (Muslims). Two East India Company officials are profiled - William Hawkins and Peter Mundy - but their respective accounts are more focused on their tortured negotiations with the Mughal authorities as they sought to further establish the East India Company as the preeminent trading institution. Lastly, we have the two well-known French travelers, François Bernier and Jean-Baptiste Tavernier, whose accounts are invaluable for glimpses into the political, philosophical, and cultural narrative of Mughal India. Fisher provides a glossary at the end of this collection to help readers with transliterated vocabulary which appears in the travel accounts.

INDEX

Thèmes : 4.2.3. Inde musulmane

\section{AUTEURS}

COLIN P. MITCHELL

Dalhousie University - Canada 